roughened with very short hairs, beneath pilose, reticulate, the veins more prominent beneath than above; stipules long-persistent, subulate lanceolate: inflorescence terminal and lateral, of simple racemes; flowers purple, on pilose pedicels ( $5^{\mathrm{mm}}$ long); bracts lanceolate, early deciduous: calyx lobes equal, obtuse, pubescent: ovary puberulent; loment 2 to 5 -jointed, decidedly stipitate, the joints reticulate-veined, $4{ }^{\mathrm{mm}}$ long and $3^{\mathrm{mm}}$ wide, with a very narrow isthmus (not quite central) rarely half as long as adjacent joints.

Collected by Dr. E. Palmer at Tequila, Jalisco, August-September I 886 (no. 398); by C. G. Pringle, on rocky hillsides near Guadalajara, Jalisco, October I, I89I (no. $3^{877}$ ); by J. N. Rose \& Jos. H. Painter, vicinity of Rio Blanco, Jalisco, September 30,1903 (no. 7492); and by C. G. Pringle on mountains about Etzatlan, Jalisco, October 2, 1903 (no. II $4 \mathrm{I}_{3}$; type, no. 460875 of the U. S. National Herbarium).-J. N. Rose and Jos. H. PaInter, U. S. National Museum.

\title{
A NEW KRYNITZKIA
}

Mr. W. N. SUKSDORF, who for a number of years has made quite extensive collections of plants in the northwest, more especially in the state of Washington, sent recently to the Gray Herbarium a consignment of specimens containing several species of particular interest. Among these rarities is a Krynitzkia which deserves an early record. Flowering specimens of this plant were first secured in the spring of Igor; and in June of the past season fruiting material was obtained. These collections have been placed at the disposal of the writer for study, and a careful comparison with the entire representation of the genus in the Gray Herbarium shows that the Suksdorf plant is most nearly related to $K$. oxycarya Benth. and $K$. rostellata Greene. From type material of both these species the Suksdorf plant differs in several important characters, and it seems best, therefore, to regard it as specifically distinct. The writer takes pleasure in dedicating the new species to its collector. The plant may be characterized as follows:

Krynitzkia Suksdorfii Greenman, n. sp.-A small annual: stem erect, 0.5 to $1.5^{\mathrm{dm}}$ high, simple or branched from the base, canous-strigose: leaves opposite below, alternate above, spatulate to linear, 0.5 to $1.5^{\mathrm{cm}}$ long, I to $3 \cdot 5^{\mathrm{mm}}$ broad, obtuse, entire, subappressed-tuberculate-hispid: flowers small, sessile: calyx deeply 5 -parted, about $2.5^{\mathrm{mm}}$ long in anthesis, pubescent with spreading slightly curved stiff hairs, persistent, becoming $4^{\mathrm{mm}}$ long in fruit and surrounding the single mature nutlet; lobes of the calyx linear, acute: corolla about $3^{\mathrm{mm}}$ in length; lobes subrotund, $\mathrm{I}^{\mathrm{mm}}$ in 
diameter: stamens adnate to the corolla-tube for about one-half its length; anthers sessile: mature nutlets narrowly ovate, $2 \cdot 5^{\mathrm{mm}}$ long, acuminate, smooth and shining, pale chocolate-colored, somewhat mottled with darker spots; the ventral surface slightly flattened and the groove bifurcated at the base.-Washington: on dry hillsides near Rockland, Klickitat County, I8 April I90I, Suksdorf, no. I495 (flowering specimen), and 8 June I9०4 (fruiting specimen); on dry hillsides near Dallas City, I7 April Igor, Suksdorf, no. 2346 (flowering specimen). Type in herb. Gray.

This species differs from $K$. oxycarya Benth. in having shorter broader leaves, somewhat larger corolla, more prominently beaked, darker colored and mottled nutlets which are bifurcately grooved on the ventral side near the base. From the Californian $K$. rostellata Greene, $K$. Suksdorfii differs in having somewhat smaller habit, shorter, broader leaves, much shorter branches of the inflorescence, slightly larger corolla with broader corolla-lobes, and shorter calyx-lobes in the fruiting state.-J. M. Greenman, Gray Herbarium. 


\section{$2 \mathrm{BHL}$ Biodiversity Heritage Library}

Greenman, J. M. 1905. "A New Krynitzkia." Botanical gazette 40(2), 146-147. https://doi.org/10.1086/328659.

View This Item Online: $\underline{\text { https://www.biodiversitylibrary.org/item/95195 }}$

DOI: https://doi.org/10.1086/328659

Permalink: https://www.biodiversitylibrary.org/partpdf/223197

\section{Holding Institution}

Missouri Botanical Garden, Peter H. Raven Library

\section{Sponsored by}

Missouri Botanical Garden

\section{Copyright \& Reuse}

Copyright Status: Public domain. The BHL considers that this work is no longer under copyright protection.

This document was created from content at the Biodiversity Heritage Library, the world's largest open access digital library for biodiversity literature and archives. Visit BHL at https://www.biodiversitylibrary.org. 